\title{
Determining and Mapping of Vegetation using GIS and Phytosociological Approach in Mount Tahan, Malaysia
}

\author{
Mohd Hasmadi, I \\ Mohd Zaki, H., Ismail Adnan, A.M., Pakhriazad H.Z. \& Muhammad Fadlli, A.Y. \\ Forest Surveying and Engineering Laboratory, Faculty of Forestry \\ Universiti Putra Malaysia, 43400 UPM, Serdang, Selangor, MALAYSIA
}

Tel: 603-8946-7220Ｅ-mail: mhasmadi@putra.upm.edu.my

The research is financed by the RUGS, Ministry of Higher Education Malaysia

\begin{abstract}
The study on lowland tropical forest plants is complicated by the extreme species diversity, very complex plant mosaic and time constraints. These impediments however do not occur in mountain forest, where habitat diversity is clearly distinguished by small homogenous plants types. Plant association and composition study were presented in this work from two locations of Mount Tahan, Malaysia the relatively untrampled and the trampled site. In each site, plant species number, vegetation cover, plant height, and species cover and frequency in untrampled and trampled areas were counted or measured. The analysis included a field survey following the relevance method of Braun-Blanquet and mapping using a GIS. The study focused on altitudinal distribution of specific plants communities located between $1900 \mathrm{~m}$ and $2140 \mathrm{~m}$ altitude. The data from field survey were mapped and analyzed in GIS. The phytosociological classification revealed that untrampled areas in Botak and Puncak sites were high in species more diversified communities compared to the trampled areas. The results showed that Leptospermum flavescens was the dominant species most in both sites (Botak and Puncak), with $48 \%$, specifically at the untrampled site. The abundance class and sociability value are also high for this species with score 4.5 out of 5 , respectively. A total number of trees in the area probably play an important role in quantifying the species richness and diversity parameters. From the study it can be concluded that GIS technique useful in developing a tree mapping system and creating a geo-database for spatial analysis. Further studies are recommended to integrate more data into the system for better evaluation.
\end{abstract}

Keywords: Mount Tahan, Plant association, Phytosociological, GIS, Mapping

\section{Introduction}

An increase in the number of visitors to Mount Tahan National Park is anticipated as a result of the government's tourism promotion in outdoor recreation in natural environments. The vegetation of Mount Tahan National Park is a major natural resource in peninsular Malaysia. The vegetations is made up of dipterocarp and montane forest and rich in fauna diversity like large mammals and endemic wildlife (Pakhriazad et al, 2009). They extend up the mountain slopes to an elevation of t $218 \mathrm{~m}$ and occupy about $60 \%$ of the National Park landscape. This area has an important place in the phytogeographical matrix due to climatic, soil, cultural and geographical characteristics. Vegetation trampling on the mountain recreation trail and camp-sites is viewed as direct disturbance as it destroys fragile above-ground plants. The increasing of human trampling in mountain trails and camping site has affected vegetations which stimulate the requirement of information on concerning environments open to human impact. In present, the effect of human trampling on vegetation and soil has been the subject in many recreation ecology studies. Perhaps the most basic information for managing natural-resource areas is a thorough knowledge of vegetation, an undisputed resource of scenic beauty, cultural heritage, wildlife habitat, and overall ecosystem function. The original Braun-Blanquet methods were modified and adapted throughout the twentieth century to meet specific needs of plant ecologists. Recently, phytosociological methods have been used extensively for the purposes of plant community classification and vegetation mapping. A review of the releve technique, its development and modification can be found in Kent and Coker (1992).

The vegetation or plants mapping nowadays are come from threefold approaches; a phytosociological basis, the use of remote sensing and GIS, and multi-scale approach including landscape ecology. The wealth of information contained in these maps is widely applied to many fields such as landscape planning, nature conservation and forestry (Bredenkamp et al., 1998; Rusanen et al., 2001). The modification of the concept of 
potential natural vegetation mapping is particularly important for small scale mapping. The influenced of GIS technique in vegetation mapping apparently superb with combination of ground studies. The GIS and vegetation classification systems in conjunction with computer-based automated field mapping techniques have been indispensable tools in the process of creating an up-to-date vegetation map. The main issues on having plants mapped spatially using GIS is to contribute in making comprehensive planning especially in protecting ecosystem. Several examples of using remote sensing and GIS in vegetation mapping were presented by Walsh et al., (1994); Li and Wu (2004); Guisan and Thuiller (2005). GIS is becoming an important tool for forest resources management in Malaysia. To achieve the sustainable forest management concept, forest managers require more intensive, precise and documented information about the forest resources, landscape features and attributes which can be gathered through GIS.Vegetation mapping utilizes both qualitative and quantitative data collection techniques in order to create a database containing the spatial location and attribute table information of the plants. Vegetation mapping commonly has been used to find the distribution of plants species, damages to the tree, area disturbances and many other factors. For many times many researches have used vegetation or land cover classes to analyze the spatial distribution of plant species (Pitkanen, 1998; Nagendra and Gadgi, 1999; Wagner et al., 2000; Hernandez-Stefanoni and Ponce-Hernandez, 2004). Besides that researcher also used vegetation or land cover for identifying habitat of animal species (French, 1999;Moreno and Halffter, 2001), or both plant and animal species (Fuller and et al., 1997). The objectives of this study, however to determine and map plant association and composition from two locations of Mount Tahan, Malaysia using GIS and phytosociological approaches, specifically at untrampled and trampled sites.

\section{Methodology}

\subsection{Description of the study area}

The specific study areas are located in two sites, which are at the Puncak and Botak sites of Mount Tahan. Mount Tahan is the highest mountain in Peninsular Malaysia and a favourite place for the climbers and hikers especially from foreign country due to its beautiful scenery along the way to peak. It takes about 4 to 5 days walking and climbing to reach the summit of Mount Tahan. The number of visitors that reached the Mount Tahan peak from 1996 to 2005 is about 2,838. The elevation of both studied sites is $2187 \mathrm{~m}$ a.s.l for the Puncak and $1932 \mathrm{~m}$ a.s.l at the Botak site. The sites are hilly with extreme slope ranging from 50 to 70 degrees. The salient difference between Puncak and Botak can be distinguished from the soils shape and types. The Botak site it has a high percentage of sandy, loam and rock; meanwhile the Puncak site is predominantly covered by humus and algae. The annual temperature of the sites is $21^{\circ} \mathrm{C}$. The locations of both sites are shown in Figure 1.

\subsection{Methods}

\subsubsection{Field sampling}

The vegetation analysis were followed a standard experimental design according to Braun-Blanquet's system (1965). The approach is by recording field observation by relevé. A relevés is a list of species observed in a plot together with estimate their abundance/dominance or cover. A $20 \mathrm{~m}$ x $20 \mathrm{~m}$ relevés plot representing trampled and untrampled were established randomly at Botak and Puncak sites to collect data on plants community composition. Untrampled sites were established about $20 \mathrm{~m}$ away from trampled site either on the left or right of camping and trekking trails, but the plot orientation was from valley toward the hill top. Elevation, aspect, and slope were determined for each releve sites. Every single plant location in the plots was recorded and measured using global positioning systems (GPS). A GPS were used to locate the centers of the plants samples and as data logger to related and additional information such as tree species, height, diameter and leaf area were added to the field form. When collecting field data, photographs of the relevés were taken for archive and reference. Because of the insufficient quantitative vegetation survey and without prior knowledge of the vegetation type in that area, the sampling and mapping is created broadly through GIS. The recorded plants later on were transferred into ArcGIS software for developing plants mapping system.

\subsubsection{GIS phase: Creating tree map and database}

Choosing the way of representing data on the map is an important step in geographic analysis. A GIS was used to produce the digital map depicting the plants of the Mount Tahan. A GIS is a computerized database designed for the management and use of spatial data. The selection decided for structure of main folder and subfolder in the GIS database. The plants data collected during field survey using GPS and were transferred into GIS. The data were double checked with field form. In GIS the plants georelational data model were stored attributes data from spatial data. The plants object-based data model stores spatial data as an attribute along with other attributes in a single system. Thus the object-based data model eliminates the complexity of coordinating and synchronizing two sets of data files as required in a split system. The preliminary plants layer in the present database does not contain 
sufficient information. Therefore, columns in the existing plants layers attribute table were added to input related information.

\subsubsection{Vegetation layer classification, abundances class and sociability value}

There are many ways that have been used to classify vegetation. Some are based on vegetation physiognomy, vegetation structure, or environmental factors. In this work for a fine scale a floristic approach by Braun-Blanquet (1965) is used for vegetation layer classification, abundance class and sociability value (Table 1). The abundance class of the vegetation was classified into six classes. Every class has been fixed to the percent of cover estimation. The estimation of cover abundance has been evaluated regardless of the number of individual tree. The class of cover abundance will be combined with class of sociability in differentiated table. The reason of using estimates is due to habitat types imposing an ordered classification on vegetation, which actually exhibits semi-continuous gradients of structure and composition-layers and species abundance/presence (Jensen, 2000). Sociability or gregariousness is an expression of horizontal pattern of species. It measures the value of clustering or contagion of the species. Begin with value number 1 for growing solitary which mean growing singly in certain area. Then another value is number 2 which perform a tree that growing in small groups of a few individuals or in small tussocks. Number 3 is for tree growing small patches, cushions or large tussocks. More then that growing in extensive patches, carpets, or broken mats is refer to value number 4 and the last one is for tree growing in great crowd or can extensive mats completely covering the whole plot. Table 1 showed abundance and sociability value used in this study. Other reason to use Braun-Blanquet method is to find constancy. Constancy refers to how many plots a species occurs in. This term is used in the Braun-Blanquet method to refer to how "constant" a species is within a set of samples. It is equivalent to frequency.

\section{Results and discussion}

\subsection{Tree map and database}

The database design has a major impact to tree mapping where it determines how the features and data are organized. A basic premise of GIS is the correlation between spatial data and features attributes (Monto et al., 2005). The design for tree database describe the conceptual for data and application including an overview of data requirements and special relationships, seven layer has been make in tree database for this study. The development of tree database with attributes is supported by the data dictionary. Basically the documentation on the database design must convey to each item concisely and completely. Information or attribute about tree in the spatial map can also be retrieved because of the existence of linkage between the features and their attribute, in other word the data dictionary itself carries information about tree (family, species and genus), DBH, Height, NumberID and coordinate X, Y for every tree. The features are queried using Simple Query Language (SQL) commands.

\subsection{Tree composition map}

The example of tree composition map is illustrated in ArcMap-GIS (Figure 2). A disturbance level for each study sites can be evaluated from tree composition. Understanding the effects of human disturbance on tree structure, composition and on the relationships among the component groups of tree species is essential in defining alternative sustainable forestry systems (Halpern and Spies, 1995; Lugo, 1995; Vetaas, 1997). From developed database, high density vegetation was at untrampled plot at Puncak. In general, human activities affect on tree cover abundance. The evaluation for cover abundance for each plot is discussed next section. An extra layer has been made for Puncak and Botak which covers $1.5 \mathrm{~km} \times 1.5 \mathrm{~km}$ for each site that contains three types of plot (trail, campsite and undisturbed), then the other layers has been clip to the new layer named (KwsnStudyPunck and KwsnStudyBotak) which completed the develop database for the site.

\subsection{Analysis of trees}

This comparison has been made to evaluate visitor impacts on tree composition in different type of plots. Plot types are categorized as trampled (trail and campsite) and untrampled (undisturbed or control). The total number of trees in Botak and Puncak is shown in Figure 3. The number of total tree different for both campsites is 129 trees. The soil factor (sandy and rocky) or geographical factor might be the main issues influences the number of tree at Botak compared to Puncak. Cole (1987) and Newsome et al. (2002) stated that the trail and campsite areas are the favorites locations that are regularly visited. Consequently, this concentration of uses at both areas will cause a massive impact. One of the most obvious physical impacts is trampling because these areas are frequently used. Besides that, another factor that made amount of tree is low at both disturbance campsite compared to undisturbed area because of placed a tent from climber and open a new trail made a damage to the side trail trees. Effect of trampling begins with an impact on vegetation when users walk on the places. Then it 
occurs to three initials effects: abrasion of vegetation, abrasion of surface soil or organic layer and compaction of soils (Hendee et al., 1990). Naturally, an ecosystem is free from biophysical disturbance caused by human activities Lesslie et al. (1988). In this study camping and climbing activities were contributes to the impacts on trees and ecosystem. A huge impact occurred in both types of the plot.

The size of trees based on diameter at breast height $(\mathrm{dbh})$ for each plot is not significant difference, where in Puncak the biggest size of tree was $8 \mathrm{~cm}$, while in Botak campsite was $10 \mathrm{~cm}$. The difference might be happened because growth for the tree is influences by climate, soil, light and the most important is nutrient. In altitude $2000 \mathrm{~m}$ a.s.l, trees gated a low light and low temperature which affected photosynthesis to the tree. The proximity to the natural conditions of a site influences the survival chances of the native flora and fauna. Diameter growth is influenced by the temperature and precipitation in the region where trees grow (Veblen et al., 1995). Those primary factors played a major role for tree growth and have been highlighted in many studies. The cause-effect relationship between sun spot and tree growth should be the solar-induced temperature/climate variability in regions where trees develop. The reversal in the correlation signal between solar activity and some meteorological/climatic signal was observed by Hoyt and Schatten (1997).

\subsection{Species composition, abundances class and sociability value}

Generally, a total of 21 species has been recorded at the Puncak and Botak campsites. The study observed that dominant species were simply diminished with different altitude, where untrampled plot contains most abundance. Species Leptospremum flavescens were dominated most in all type of plot 48\% (Table 2). This followed by species Rhodoleia championii with only 7.63\%. The other species recorded were Leptospremum flavescens, Rhodoleia championii, Beackea frutescens, Dacrydium beccarii and Tristaniopsis fruticosa, where all of these species can survive and adapt with disturbances. The genus Leptospermum is widely cultivated in residential areas, especially in cooler climates and higher elevations. Gunung Tahan is suitable habitat for these species. Species in the genus Leptospermum are native mostly from Australia, from areas of Queensland, New South Wales, Lord Howe Island, and Tasmania, with a few species also from South East Asia to New Zealand, occurring mostly in rainforest and semi-arid areas (Brickell and Zuk, 1997). In fact, only a few species in South East Asia has been founded, less found in Malaysia but the suitable habitat for this species mostly in rainforest and semi-arid areas. Moreover, the mountainous topography of Malaysia provides more possibilities for refuge zones, alleviating the impact of climatic disturbances. The other name or synonym for this species is $L$. polygalifolium [syn. L.flavescens ] (Wagner et al., 1999).

Analysis revealed that only a few numbers of trees were over $2 \mathrm{~m}$ in height (S), where the height of tree probably 2-7.9 $\mathrm{m}$ and were considered as shrubs, Table 3 shows the cover abundances and sociability value at trampled and untrampled plot at Puncak and Botak sites. Most of the species recorded was shrubs, and only Lindera reticulosa were recorded at the untrampled plot at Puncak with 5\% of abundance. Symbol $\mathrm{F}$ is a frequency of the species. The only species that appeared in all plott Leptospermum flavescens was recorded with higher sociability value (5) at trampled (Puncak) and untrampled (Botak). This indicated that this species growing in large crowd and almost pure stands with cover over than $76 \%$ of the area. In trampled site (Puncak) even trees has shown a high cover abundance and sociability (4.5), but this plot contains less number of species. Both untrampled plots at Puncak and Botak showed a high level of abundance and sociability, while undisturbed plot at Botak, seven species presence with lower abundances level where only few individuals species occurred sparsely, covering less than $5 \%$.

\section{Conclusions}

Precise vegetation mapping and details resource classification are needed for ecosystem level assessment. A quantitative assessment of the composition of the vegetation is useful to describe the full range of variation for ecological management from species level to bioregional level. This study provides the baseline of phytosociological analysis and mapping using a GIS of Mount Tahan. The new vegetation map coupled with GIS analysis provides a means for making informed management decisions about the relative extent and nature of vegetation. The vegetation map will also serve as an aid in the evaluation of potential wildlife habitat and be used to assess the possible impacts of human activities in the Mount Tahan. The results are useful to resources manager for number of purposes e.g. modeling the distribution of rare plants and monitoring change in the Mount Tahan trail and camping sites over time. It can be concluded that different plant species react differently to human trampling. The composition of plants community in the Mount Tahan is important to that community's survival against human trampling. Future study is needed to investigate how and to what extent human trampling affect of the highland wilderness environment and its natural processes. The magnitude of difference in vegetation impact between vegetation types in the Mount Tahan varied with trampling frequency. The amount of 
impact generally increases as trampling frequency increases. Any activity that involves surface disturbance, whether the activity is vegetation management, development, or changes in recreational use, should consider as disturbances. A mitigation effort such as rescheduling the camp-site opening should be developed to reduce not only ground cover disturbance but to the soil loss, and soil compaction.

\section{References}

Braun-Blanquet, J. (1965). Plant Sociology. The Study of Plant Communities. Hafner, London.

Bredenkamp, G, Milan, C, Hagen, S.F., Zdenka, N and Eddy, V.D.M. (1998). Vegetation Mapping: Theory, Methods and Case Studies. Applied Vegetation Science, 1: 161-266.

Brickell, C. and J. D., Zuk. (1997). The American Horticultural Society. A-Z Encyclopedia.

Cole, D. N. (1987). Research on soil and vegetation in wilderness : A state-of-knowledge review. In R.C Lucas (comp.) Proceedings-National wilderness Research Conference : Issues, State-of-knowledge, Future Directions, July 23-26, 1987, Fort Collins.:pp:135-177

French, K. (1999). Spatial variability in species composition in birds and insects. Journal of Insect Conservation, 3:183-189.

Fuller, R. M., G. B. Groom, S. Mugisha, P. Ipulet, D. Pomeroy, A. Katende, R. Bailey, and Ogutu-Ohwayo, R. (1997). The integration of field survey and remote sensing for biodiversity assessment: a case study in the tropical forest and wetlands of Sango Bay, Uganda. Journal of Biological Conservation, 86:379-391.

Guisan, A. and Thuiller, W. (2005). Predicting species distribution: offering more than simple habitat models. Journal of Ecology Letters, 8 (9): 993-1009.

Halpern C.B. and Spies, T.A. (1995). Plant species diversity in natural and managed forests of the Pacific Northwest. Journal of Ecological Applications, 5: 913-934.

Hendee, J.C., G.H. Stankey and Lucas, R.C. (1990). Wilderness management (2 ${ }^{\text {nd }}$ ed.), Golden Co.North American Press.

Hernandez-Stefanoni, J. L. and Ponce-Hernandez, R. (2004). Mapping the spatial distribution of plant diversity indices in a tropical forest using multi-spectral satellite image classification and field measurements. Journal of Biodiversity and Conservation, 13: 2599-2621.

Hoyt, D. V. and Schatten, K. H. (1997). The role of the sun in climate change. Oxford University Press. 280p.

Jensen, J. R. (2000). Remote sensing of environment: An earth resource perspective. Prentice Hall, Englewood Cliffs, New Jersey.

Johnson J. M. (2003). Geographic information. Greenwood Publishing Group. 178p.

Kent, M., and Coker, P. (1992). Vegetation Description and Analysis. Bellhaven Press, London, England.

Lesslie, R.G., B.G., Mackey and Preece, K.M. (1988). A computer-based method for the evaluation of wilderness. Environment Conservation, 15 (31):225.

Li, H. and Wu, J. (2004). Use and misuse of landscape indices. Landscape Ecology, 19 (4): 389-399.

Lugo A.E. (1995). Management of tropical biodiversity. Ecological Applications 5: 956-961.

Monto, m., L. S. Ganesh and Varghese, K. (2005). Sustainability and human settlements: fundamental issues, modeling and simulations. SAGE. 139p.

Moreno, C. E., and Halffter, G. (2001). Spatial and temporal analysis of a, b, and g diversities of bats in a fragmented landscape. Biodiversity and Conservation, 10:367-382.

Nagendra, H., and Gadgil, M. (1999). Satellite imagery as a tool for monitoring species diversity: An assessment. Journal of Applied Ecology, 36:388-397.

Newsome, D., S.A. Moore and Dowling, R.K. (2002). Natural area tourism. Clevedon: Channel View Publications.

Pakhriazad,H.Z., Aida, H.M.K., Mohd Hasmadi, I. and Kamaruzaman, J. (2009). Historical and Current Legislations of Taman Negara (National Park), Peninsular Malaysia. J. of Politics and Law, 2(1):44-49.

Pitkanen, S. (1998). The use of diversity indices to assess the diversity of vegetation in managed boreal forest. Forest Ecology and Management, 112:121-137. 
Rusanen, J., Muilu, T., Colpaert, A. and Naukkarinen, A. (2001). Finnish socio-economic grid data, GIS and the hidden geography of unemployment. Tijdschrift Voor Economische en Sociale Geografie, 92(2):139-147.

Veblen, T.T., Burns, B.R.,Kitzberger,T., Lara, A. And Villaba, R. (1995). The ecology of the conifers of southern South America In: N. Enright and R. Hill (eds). Ecology of the Southern Conifers. Melbourne. Melbourne University Press.

Vetaas, O.R. (1997). The effect of canopy disturbance on species richness in central Himalayan oak forests. Plant Ecology, 132:29-38.

Wagner, H., O. Wildi, and K. Ewald, C. (2000). Additive partitioning of plant species diversity in an agricultural mosaic landscape. Landscape Ecology, 15:219-227.

Wagner, W.L., D.R. Herbst, and Sohmer, S.H. (1999). Manual of the flowering plants of garden plants. DK Publishing, Inc. New York.

Walsh, S.J, Davis, F.W. and Peet, R.K. (1994). Application of Remote Sensing and GIS in Vegetation Science. Journal Vegetation Science, 5:609-756.

Table 1. Abundance class and sociability value

\begin{tabular}{|cl|}
\hline \multicolumn{2}{|c|}{ Abundance class } \\
\hline Class & \multicolumn{1}{c|}{ Range of cover or abundance (\%) } \\
\hline 5 & $75-100$ cover of the total area, regardless the numbers of individuals \\
4 & $50-75$ cover of the total area, regardless the numbers of individuals \\
3 & $25-50$ cover of the total area, regardless the numbers of individuals \\
2 & $5-25$ cover of the total area, or usually abundant thought $<5 \%$ cover \\
& Covering $<5 \%$ the plot are but either abundance with very low cover or $<$ abundant \\
1 & but more cover \\
\hline Sociability value & \\
\hline Value & Growing in large crowd, almost pure stands $(>76 \%)$ \\
\hline 5 & Growing in small colonies or carpets $(51-75 \%)$ \\
4 & Forming small patches or cushions $(26 \%-50 \%)$ \\
2 & Forming small but dense clumps \\
1 & Growing singly (solitary) \\
\hline
\end{tabular}


Table 2. Species composition /dominance in trampled and untrampled sites

\begin{tabular}{|l|l|c|c|c|}
\hline No. Species & \multicolumn{2}{|c|}{ Site } & type \\
& & Trampled & Untrampled & \\
\hline & & 72 & 161 & 48.0 \\
\hline 1 & Leptospermum flavescens & 13 & 23 & 7.4 \\
\hline 2 & Beackea frutescens & 0 & 27 & 5.6 \\
\hline 3 & Eugenia sp.63 & 3 & 34 & 7.6 \\
\hline 4 & Rhodoleia championii & 0 & 16 & 3.3 \\
\hline 5 & Rhododendron wrayi & 3 & 25 & 5.8 \\
\hline 6 & Dacrydium elatum & 6 & 15 & 4.3 \\
\hline 7 & Dacrydium beccarii & 6 & 13 & 3.9 \\
\hline 8 & Vaccinium viscifolium King \& Gamble var. viscifolium & 2 & 1 & 0.8 \\
\hline 9 & Vaccinium viscifolium var. viscifolium & 3 & 27 & 6.2 \\
\hline 10 & Tristaniopsis fruticosa & 4 & 0 & 0.8 \\
\hline 11 & Rhododendron malayanum & 1 & 5 & 1.2 \\
\hline 12 & Styphelia malayana & 1 & 5 & 1.2 \\
\hline 13 & Vaccinium bracteatum & 5 & 0 & 1.1 \\
\hline 14 & Vaccinium loranthifolium & 0 & 3 & 0.6 \\
\hline 15 & Neolitsea zeylanica & 3 & 1 & 0.8 \\
\hline 16 & Melicope pahangensis & 0 & 2 & 0.4 \\
\hline 17 & Lindera reticulosa & 0 & 1 & 0.2 \\
\hline 18 & Lindera Montana & 0 & 1 & 0.2 \\
\hline 19 & Erica Unidentified & 0 & 1 & 0.2 \\
\hline 20 & Rhododenron Unidentified & 0 & 2 & 0.4 \\
\hline 21 & Syzygium Unidentified & 122 & 363 & $100 \%$ \\
\hline & Total species & & & \\
\hline
\end{tabular}


Table 3. Result of cover abundances and sociability

\begin{tabular}{|c|c|c|c|c|c|}
\hline & \multicolumn{2}{|c|}{ Puncak site } & \multicolumn{2}{|c|}{ Botal site } & $\mathbf{F}$ \\
\hline Vegetation sample reference number & Trampled & Untrampled & Trampled & Untrampled & \\
\hline Vegetation sample size (m) & $20 \times 10$ & $20 \times 10$ & $20 \times 10$ & $20 \times 10$ & \\
\hline Height of tree layer ST & & & & & \\
\hline Height of tree layer T1 & & & & & \\
\hline Height of tree layer T2 & & & & & \\
\hline Height of tree layer $S$ & 3 & 52 & & 9 & \\
\hline Height of tree layer $H$ & $<5 \mathrm{~cm} \mathrm{DBH}$ & $<5 \mathrm{~cm} \mathrm{DBH}$ & $<5 \mathrm{~cm} \mathrm{DBH}$ & $<5 \mathrm{~cm} \mathrm{DBH}$ & \\
\hline Number of species & 10 & 13 & 11 & 9 & \\
\hline Number of tree $<5 \mathrm{~cm}$ DBH & 68 & 184 & 52 & 117 & \\
\hline Total tree & 71 & 236 & 52 & 126 & \\
\hline Species & \multicolumn{5}{|c|}{ Cover Abundance Class / Sociability } \\
\hline Leptospermum flavescens $(\mathrm{S}, \mathrm{H})$ & 4.5 & 3.2 & 3.8 & 4.5 & 6 \\
\hline Beackea frutescens $(\mathrm{H})$ & 2.2 & 2.2 & 2.8 & 1.1 & 5 \\
\hline Eugenia sp.63(S,H) & & 2.2 & & & 1 \\
\hline Rhodoleia championii $(\mathrm{S}, \mathrm{H})$ & & 2.2 & 2.2 & 2.2 & 4 \\
\hline Rhododendron wrayi $(\mathrm{S}, \mathrm{H})$ & & 2.2 & & + & 2 \\
\hline Dacrydium elatum $(\mathrm{S}, \mathrm{H})$ & 1.1 & 1.1 & 2.2 & 2.2 & 4 \\
\hline Dacrydium beccarii $(\mathrm{S}, \mathrm{H})$ & 2.2 & 1.1 & + & 2.2 & 4 \\
\hline Vaccinium viscifolium King \& Gamble & & & & & \\
\hline var. & & & & & \\
\hline $\operatorname{viscifolium}(\mathrm{S}, \mathrm{H})$ & 2.2 & 2.2 & & & 2 \\
\hline Vaccinium viscifolium var. & & & & & \\
\hline viscifolium $(\mathrm{S}, \mathrm{H})$ & & & 2 & + & 2 \\
\hline Tristaniopsis fruticosa $(\mathrm{S}, \mathrm{H})$ & 1.1 & 2.2 & & 2.2 & 4 \\
\hline Rhododendron malayanum $(\mathrm{H})$ & 2.2 & & & & 1 \\
\hline Styphelia malayana $(\mathrm{S}, \mathrm{H})$ & + & + & & & 2 \\
\hline Vaccinium bracteatum $(\mathrm{H})$ & & & + & 1.1 & 2 \\
\hline Vaccinium loranthifolium $(\mathrm{H})$ & & & 3.3 & & 1 \\
\hline Neolitsea zeylanica $(\mathrm{H})$ & & + & & & 1 \\
\hline Melicope pahangensis $(\mathrm{H})$ & & & 2.2 & + & 2 \\
\hline Lindera reticulosa $(\mathrm{S}, \mathrm{H})$ & & + & & & 1 \\
\hline Lindera montana $(\mathrm{H})$ & & & & + & 1 \\
\hline Erica Unidentified $(\mathrm{H})$ & & & & + & 1 \\
\hline Rhododenron Unidentified $(\mathrm{H})$ & & & & + & 1 \\
\hline Syzygium Unidentified $(\mathrm{S}, \mathrm{H})$ & & & & + & 1 \\
\hline
\end{tabular}




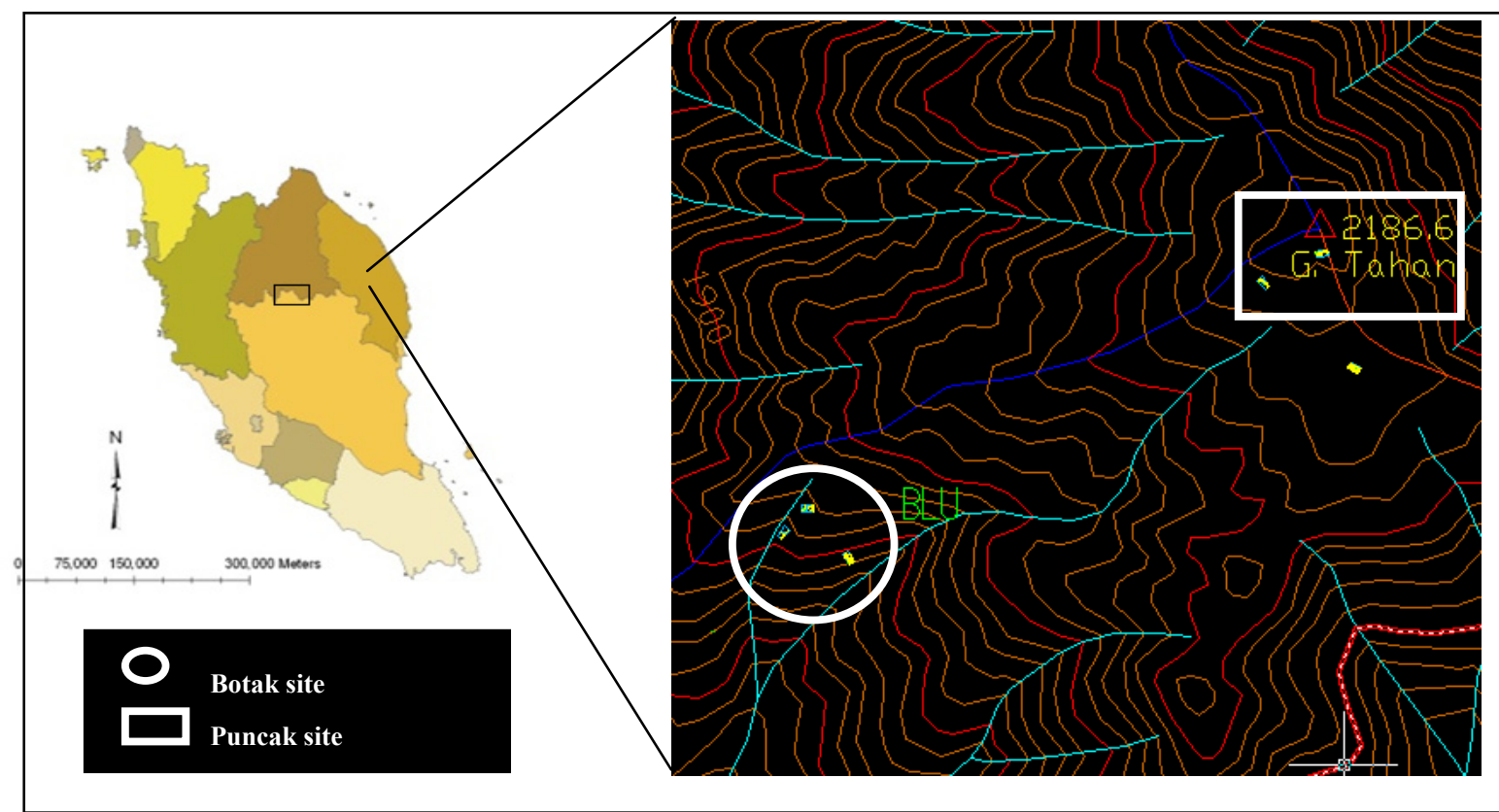

Figure 1. Map of the study area

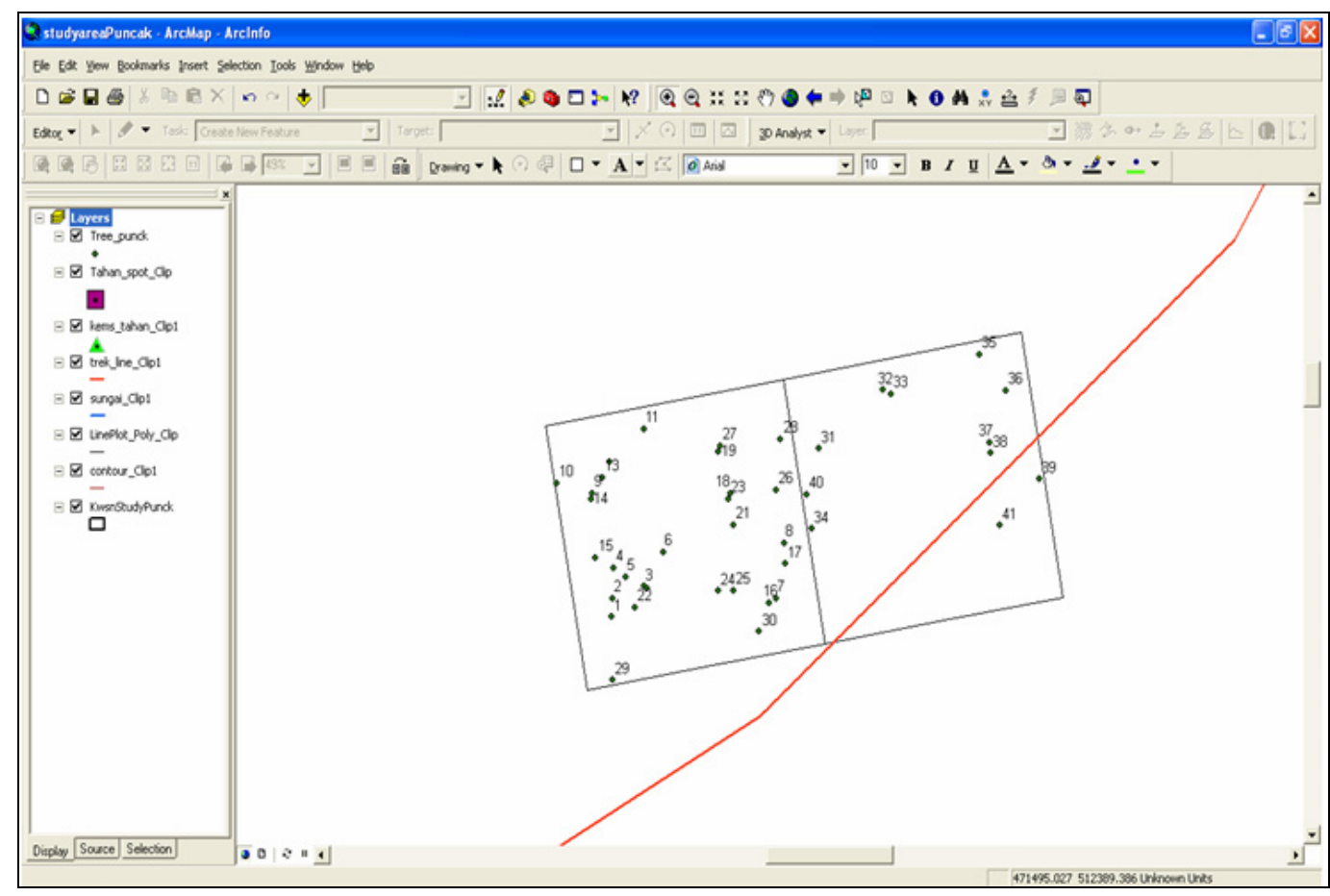

Figure 2. An example window of tree composition in ArcMap-GIS at Puncak site 


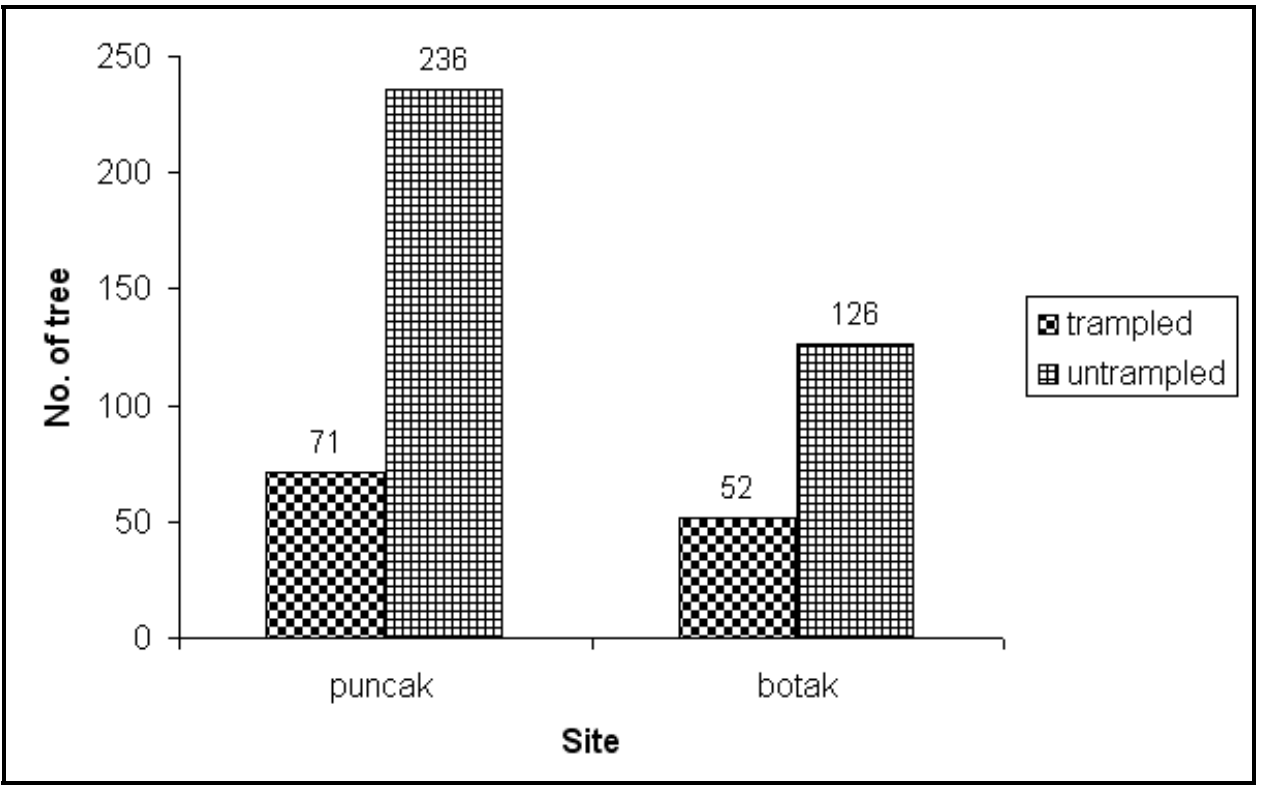

Figure 3. Comparison a number of total trees at trampled and untrampled area at Puncak and Botak site 